\title{
Comparing Models of Problem and Project-Based Learning (PBL) Courses and Student Engagement in Civil Engineering in Qatar
}

\author{
Khalid Kamal Naji ${ }^{1}$, Usama Ebead ${ }^{1}$, Abdulla Khalid Al-Ali ${ }^{1}$, Xiangyun Du ${ }^{2 *}$ \\ ${ }^{1}$ College of Engineering Qatar University, QATAR \\ ${ }^{2}$ College of Education, Qatar University, QATAR
}

Received 5 January 2020 - Accepted 7 May 2020

\begin{abstract}
Background: While improved student engagement has been highlighted as an essential goal and a major outcome of Problem and Project-Based learning (PBL), little empirical evidence has been provided regarding types and forms of student engagement.

Material and method: The study explored forms of student engagement in PBL settings, drawing on empirical data of observations and group interviews with 23 project teams (116 students) in four different PBL undergraduate civil engineering courses at Qatar University.

Results: The study identified four patterns of student engagement in a PBL setting. Participants reported significant indicators of the first two patterns - engagement as autonomy and as connection. Regarding the other two indicators, namely relational and emotional engagement, they reported positive yet slightly fewer indicators. Three factors were identified that influenced student engagement in a project teams, namely PBL types and its appropriateness to the nature of the course, students' prior experiences with PBL, and team dynamics.

Conclusions: These results facilitate the establishment of an institutional framework supporting a progressive approach to embracing PBL. In this framework PBL implementation begins with diverse practices at the course level and has systemic change as its ultimate goal. This framework particularly aims to support an institutionalized approach to transition to PBL in a socio-cultural context (e.g., a non-western context) where instructors are as the primary and authoritative source of knowledge. The overall outcome of the study supports management of change from a lecturebased mode to PBL in a non-western context.
\end{abstract}

Keywords: PBL implementation models, student engagement, civil engineering, Qatar

\section{INTRODUCTION}

Since engineering graduates are expected to work on complex problems in project-based teams, engineering curricula are increasingly incorporating Problem and/or Project-based learning (PBL) (ABET, 2016; Graham, 2018). While the current literature collectively agrees that PBL is a useful instructional methodology for addressing the learning outcomes set by accreditation requirements, such as ABET (Felder \& Brent, 2003), and for providing the competences needed for the sustainable development of education (Thomas, 2009), the majority of the literature has been based on the assumption that all PBL stems from the same practices across engineering disciplines. Although efforts have been made to distinguish PBL by types and models (Jonassen, 2011; Sabin-Baden, 2014), the main focus has been on various definition of the "problems," and little has been discussed in regard to the diverse practices of using projects (Van Barneveld \& Strobel, 2019) - an essential component of PBL in engineering education.

Although a systemic change in engineering education, which would include the integration of current lecture-based curricula, is necessary in order to reach the ultimate goal of competency development, many engineering institutions experience obstacles to dramatic change due to the pressure of accreditation and educational history and policy (Du \& Chaaban, 2020; 


\section{Contribution to the literature}

- The study contributes to the literature on PBL implementation in engineering education by providing empirical evidence of student engagement while comparing different PBL courses.

- The study identified team-based patterns regarding four different types of engagement, which were influenced by the nature of the course, students' prior experiences with PBL, and team dynamics.

- A framework is proposed to support an institutionalized vision and plan to progressively manage the change from a lecture-based mode to PBL in a non-western context.

Kolmos, 2017). A recent review (Chen, Kolmos, \& Du, 2020) of various forms of PBL implementation found that while 73 of the 108 identified pieces of PBL literature in engineering education report practices at the course level, the course designs of these studies combine multiple features crossing the nine PBL categories suggested by Sabin-Baden (2014). The multi-faceted practices of implementing PBL may be attributed to its context-bound factors, including instructors' and students' readiness for change and institutional conditions (Graham, 2018; Hmelo-Silver, 2012; Van Barneveld \& Strobel, 2011). Each of these factors may define and distinguish the instructor's choice of PBL practices, which in turn, impacts student engagement with learning (Trowler, \& Trowler, 2010). Without deeper insight into these contextual factors, research into classroom practice and course design will be of limited efficacy in helping researchers and institutions overcome organizational impediments to change.

Therefore, there is a need to compare diverse PBL practices in relation to their given contexts and in terms of student engagement. In particular, there are unique issues surrounding PBL implementation in some nonWestern socio-cultural contexts in which instructors and students have no prior experience with PBL and institutional supportive mechanisms are lacking. While a considerable body of literature has focused on student satisfaction, feedback, and learning gains from the perspectives of attitudes, motivation, and performance in PBL, and while improvement of student engagement has been mentioned as an essential goal and major outcome of PBL, little empirical evidence has been provided regarding the actual examination of student engagement in a PBL setting (Savin-Baden, 2014).

To meet this need, this study aims to explore collective student engagement in the context of four different modes of implementing PBL at the course level within a civil and structural engineering program in Qatar. The outcome of the study contributes to the establishment of an institutional framework of diverse models of PBL implementation at the course level to support the transition from a lectured-based curriculum to a PBL curriculum as an ultimate goal. The study took place in the context of a pedagogical change from lecture-based to PBL methodology initiated by civil engineering instructors. Although over the last decade, higher education institutions in Qatar have been called upon to make pedagogical changes to provide students with profession-related competences, and a few change initiatives have taken place in some courses (Du, Ebead, Sabah, Ma, \& Naji, 2019; Du, Naji, Sabah, \& Ebead, 2020), a lecture-based approach has remained the prevailing teaching method (Sabah \& Du, 2018). Multiple qualitative data were generated from classroom observation and group interviews of 116 students who made up the 23 project teams within the four civil engineering courses at undergraduate programs at College of Engineering, Qatar University.

\section{LITERATURE REVIEW}

\section{PBL: Definitions, Principles, Diversity of Types and Practices}

The term PBL has been defined in various ways. To emphasize a problem, PBL may refer to "an instructional learner-centered approach that empowers learners to conduct research, integrate theory and practice, and apply knowledge and skills to develop a viable solution to a defined problem" (Savery, 2015, p. 7). The focus on the project component of the definition highlights the solution to a problem obtained within a set timeline, resulting in an end product (e.g., reports, designs) (Helle, Tynjala" \& Olkinuora, 2006) and linking to the context of teamwork (De Graaff \& Kolmos, 2003).

In this study, the definition encompasses all three essential components of PBL in engineering education, namely, problem- and project-based learning in a teamwork setting (De Graaff \& Kolmos, 2003). In this way, PBL is both a philosophy and a pedagogy guiding the practice of teaching and learning in engineering education. From a social constructivism perspective, learners generate meanings through participating in and engaging with activities rather than merely listening to lectures and memorizing the "right" answers (Jonassen, 2011). Relying on learners' prior experiences and using a problem as the starting point of a learning process facilitate cognitive development (De Graaff \& Kolmos, 2003). Within a timeline, learners work on a unique task (project) that may be complex and contextual, applying theory to practice in an analytical approach within and beyond a discipline. From a socio-cultural perspective, PBL highlights learners' engagement in activities and their co-constructed understanding through an interactive process (Savery, 2015). Thus, through 
working in a team, learners develop strategies and collective engagement through collaborative learning, which demands sense-making, dialogue, interaction, and constructive communication.

Over the decades, efforts have been made to categorize and distinguish PBL practices. The implementation of PBL has been categorized at the course level, cross-course level, program level and curriculum level (Kolmos, 2017). Focusing on the formulation of problems, Jonassen (2011) proposed a typology of problems on a continuum ranging from well-structured to ill-structured, including story problems, rule-using, decision-making, troubleshooting, diagnosis-solution, strategic performance, policy, design, and dilemmas. Savin-Baden (2014), using the term "constellation," further categorized nine types of PBL problems according to type, interaction form, knowledge focus, facilitation form, assessment methods, and learning emphasis. These types are: problem-based learning for knowledge management, problem-based learning through activity, project-led problem-based learning, problem-based learning for practical capabilities, problem-based learning for design-based learning, problem-based learning for critical understanding, problem-based learning for multimodal reasoning, collaborative distributed problem-based learning, and problem-based learning for transformation and social reform. Yet despite this overall robustness of PBL research, research involving PBL in engineering education demands more attention with empirical evidence from different educational, societal and cultural contexts. In addition, most studies in this field implement PBL at the course level and adopt multiple features of the categorized problem types and ways of organizing projects according to the course's demands (Van Barneveld \& Strobel, 2019).

Although transitioning a whole program and institution to PBL at a systemic level is ideal to maximize student learning (Kolmos, 2017), in reality, institutional movement to PBL initially takes place at the course level, based on the instructors' interests and initiation $(\mathrm{Du}$, Ebead, Sabah, Ma, \& Naji, 2019; Du, Naji, Sabah, \& Ebead, 2020). The extent to which the instructor may restructure and adjust the course to PBL is highly related to instructor- and student-based factors including their prior experiences, beliefs, motivation, and PBL-related skills, as well as socio-cultural factors such as institutional culture, support, policy, curricula conditions and physical facilities, and the educational system (Du, Kolmos, Ahmed, Spliid, Lyngdorf, \& Ruan, 2020; Van Barneveld \& Strobel, 2011).

\section{PBL for Student Engagement in Engineering Education}

While the current literature has collectively agreed that PBL is valuable for student learning in multiple respects (Helle, Tynjalä, \& Olkinuora, 2006; Strobel \& van Barneveld, 2009), the effectiveness of PBL in engineering education still has not been established and demands more empirical evidence (Borrego, Karlin, McNair, \& Beddoes, 2013). Although it is commonly believed that PBL is valuable in providing engineering students with the collaboration and teamwork skills required in their future profession (Borrego, Karlin, McNair, \& Beddoes, 2013), there is limited empirical evidence regarding student engagement (Savin-Baden, 2014), and even less is known about how students make collaborative efforts toward engagement within a team project.

Embedded in constructivism, student engagement, referring to "the extent to which students are engaging in activities that higher education research has shown to be linked with high-quality learning outcomes" (Krause \& Coates, 2008, p. 493), has received increasing attention in higher education in general and engineering education in particular. Individuals' involvement and effort to be engaged in the class are not only a reflection of their own learning processes and predict their learning outcomes but also play a central role in determining quality development at the institutional level (Trowler \& Trowler, 2010).

Although intensive efforts have been made to examine the concept of student engagement in higher educational settings, the outcomes are highly contextual and inclusive and are closely related to the conditions in their learning environments, such as instructors' choices of methods, classroom activities, course contents, design, and assessment methods (Trowler \& Trowler, 2010). In the PBL literature, student engagement has often been reported as having a major effect on the learning process and impacting outcomes, yet a clear definition is not usually provided, nor is empirical support. Even less empirical evidence has been provided in the engineering education literature.

Studies conducted in the context of engineering education include work by Case (2007), who emphasized that engineering students engage with their study through "the connection in the context of a relationship which a student desires or expects to belong to" (p. 120). Although not specifically within the context of engineering education, other work related to the study at hand includes research by Wimpenny and SavinBaden (2013). Sharing the focus on interaction between individuals and their contexts, Wimpenny and SavinBaden (2013) categorized student engagement in higher educational settings based on a research synthesis of the previous qualitative data on student engagement. In this study, four patterns of student engagement were identified based on published qualitative data, namely, 1) inter-relational engagement, referring to student committeement to relationships such as student-tutor, student-student, student-family and student-career; 2) engagement as autonomy, referring to how students shift from unfamiliarity and self-consciousness to self- 
sufficiency in learning; 3) emotional engagement, illustrated by intra-personal capacity for resilience and persistence; and 4) engagement as connections and reducing disjunction in challenges handling. Further, Kahu (2013) suggests understanding engagement as a dynamic continuum with different locations, such as tasks, classrooms, and institutions, emphasizing the mutually influential relationships between psychosocial (both emotional and cognitive), socio-cultural, and structural factors on student engagement.

\section{PBL in Civil and Structural Engineering}

Recent decades have witnessed a dramatic change to the nature of civil and structural engineering as academic disciplines, with newly invented materials and new ways of analyzing structures and modeling designs necessitating new skills and competences for civil engineering graduates (Beagon, Niall \& Fhloinn, 2019). PBL has been regarded as suitable to address these needs due to the focus of civil and structural engineering on the design, construction, management, and sustainability of the construction environment (Ahern, 2010; Hezmi et al., 2017).

Although the majority of the PBL literature in civil engineering tends to be an account of practice from the instructors' perspective or course feedback from students (Shekhar \& Borrego, 2017), a few very recent studies have reported empirical evidence of students' development of deep learning (Du, Ebead, Sabah, Ma, \& Naji, 2019) and self-directed learning (Du, Naji, Sabah, \& Ebead, 2020) through collaborative learning in project teams. Also is newly reported includes students' selfreported improvement in professional skills for civil engineering, namely, communication, problem-solving, use of modern technological tools, teamwork and leadership (Hezmi et al., 2017). In addition, based on student feedback, Shekhar and Borrego (2017) provided detailed suggestions on how to overcome challenges in implementing PBL in a civil engineering course.

Overall, although the current literature on PBL in civil and structural engineering generally agrees that PBL is an effective approach, there is a lack of a clear understanding of how PBL is implemented in response to different course demands. Further, little is known on how the different ways of implementing PBL affect student engagement in their learning process and learning outcomes. Therefore, this study aims to explore engineering students' engagement in different PBL practices at the course level. In particular, the study intends to answer the following research questions:

1) In which ways do engineering students develop different forms of engagement in different PBL courses?

2) What are the supporting and constraining factors for students' forms of engagement?

\section{METHODS}

\section{Four PBL Course Descriptions}

The study was carried out in four civil engineering undergraduate courses organized by two instructors at College of Engineering, Qatar University during 20182019. Being a leading University in Qatar, diverse student-centered learning methods have been encouraged to be adopted at all courses. The instructors had voluntarily attended two major PBL workshops, and Course 1 and 3 were their first time implementing PBL and course 2 and 4 were their second time. Course 1 and 2 were organized by the same instructor and Course 3 and 4 were organized by the same instructor. Course 1 and 3 were the first PBL experience for both instructors and Course 2 and 4 were their second PBL experiences. Both instructors served as coauthors of the study to enhance a research-based approach to pedagogical innovation. Both instructors followed the PBL principles in the course designs, including problem orientation, project organization and teamwork (Du, Ebead, Sabah, Ma, \& Naji, 2019; Du, Naji, Sabah, \& Ebead, 2020). Students worked in a project team with 56 students in each team on projects with 4 months' duration. The course process provided multiple sources to support student learning. Below are descriptions of the PBL setting of each course.

\section{Course 1: Design of Reinforced Concrete (RC) Structures (RC structures)}

When this course was offered in Spring 2018, it was the first time to be offered in PBL mode after several offering as a conventional lecture-based learning (LBL) counterpart. At the time the students are offered this course, they are mostly familiar with its topics after they complete its pre-requisite course, which is Course 2 below. This prerequisite course later was offered using also PBL mode by the same instructor when teaching one section of this course. However, other instructors teach this course entirely using a LBL model. Therefore, all the students attended this course in Spring 2018 had no PBL prior experience. The course focused on the design of different kinds of reinforced concrete structures, including two-way slabs, slender columns, continuous beams, and shallow foundations. The instructor adopted an open-ended approach to defining the problem, whereby the students identified the project problem statement (a short statement along with architectural drawings defining the problem and outlining the scope of work). When shifting from LBL to PBL learning, it is very important for the instructor to ensure that the course objectives would be achieved as other offering of the same course did. The course objectives to be achieved in LBL mode were to analyze and design two-way slabs and two-way plates, slender columns, continuous beams and isolated wall footings, isolated footings and 
combined footings. Through offering this course using PBL, the following additional intended learning outcomes were enabled: integrating standards and multiple realistic constraints in design, formulating and providing a solution of a real-life problem through utilizing effectively up-to-date technology in the analysis and design tools for reinforced concrete structures, teamworking and creating a professional report and be able to professionally present work

To identify the project problem statement, the students communicated with local industry professionals and design offices to obtain the architectural drawings. The complete formation of the problem statements was achieved with the help of the instructor through their coaching of the students. There was large variation in the complexity of the problem, and there was also variation in the work required to solve some of the basic conceptual problems that the groups faced. Therefore, the instructor made some modifications to the project problem statements to maintain fairness among the groups.

Detailed calculations and final structural drawings were mandatory as a final product of the design process, as these are normally produced in consulting engineering offices. To this end, three 50-minute PBL sessions were conducted every week throughout the Spring 2018 semester to follow up on the progress of the student group work. During the PBL session, each group was engaged in discussions and worked on the project to supplement their out-of-class efforts, which included finding learning resources, such as the instructor's notes and handouts, textbooks, internet sources, and design codes. Although the project problem statement was identified through industry contacts, these contacts were not used as a design resource, apparently due to time constraints. The role of the instructor was to provide comments on the students' work, give directions, and realign the students' efforts toward successful implementation of the project. In assessing this course, $75 \%$ of the total grade was based on the group work through two interim reports, a final report, and group presentations. An individual final exam constituted the remaining $25 \%$. It is worth mentioning that the group presentations were only communicated with the instructor as there were no group-to-group presentations to simply assess each group based on their work without being affected by the work of other groups.

\section{Course 2: RC members}

The course, focusing on the design of reinforced concrete members, exposed students to design for the first time and was offered as a pre-requisite course for course 1 as described above. The instructor (same instructor for course 1) adopted a closed-ended approach to defining the problem and work on solutions, so that the students were provided a specific problem statement to work on instead of adopting an open-end where the students would come up with the problem statement. Closed-end approach here in this course is suitable for an elementary course in which the students are new to the basic elements of design or reinforced concrete members and to the relevant concepts and theories. The problem statement included the same project idea but different variables and parameters that made the project calculations and final design values different from one group to another. The class was divided into four groups, with 5-6 students each. The mandates of the project were to create detailed calculations as a final product of the design process normally exercised in consulting engineering offices. To this end, two 50-minute PBL sessions were conducted every week throughout the Fall 2018 semester to follow up on the progress of student group work. Moreover, one 50-minute regular lecture per week was offered to present the new common concepts and to prepare students for the PBL sessions.

During the PBL session, each group was engaged in discussion and worked on the project to supplement their out-of-class efforts; these included finding learning resources, such as the instructor's notes and handouts, textbooks, internet sources, and design codes. The role of the instructor was to coach students through engagement in these discussions.

Multiple learning sources were provided during the PBL process. Considering the fact that this course is an elementary design course, some of the concepts and theories were provided in the form of lectures. Moreover, the instructor offered regular homework assignments to be solved and submitted in a form of teamwork. Such assignment aimed at enhancing students' abilities to conduct specific calculations, to work on similar tasks in the project, and to promote communication among all members of the class.

In assessing this course, $60 \%$ of the total grade was based on the group work through one interim report, a final report, group presentations, and specially designed group homework assignments, constituting $5 \%$ of the total grade, that enabled and supported the mandate of the project. Individual midterm and final exams constituted the remaining $40 \%$. Same as course 1 , the group presentations were only given before the instructor not to other groups.

A distinction has to be made here between the assessment methods for RC Members and RC Structures. The latter is an advanced design course, offered to the $4^{\text {th }}$ year civil engineering students while the former is a preliminary design course, a prerequisite of the latter, where the students are exposed to the design concepts and theories for the first time. Hence, on one hand, RC Structures students applied open ended PBL with 75\% of the total grade was related to the project and $25 \%$ was related to the only final exam. The $75 \%$ project related 
grade was divided so that the weight of the interim reports and final reports was while that of the presentation was 15\%. Students offered RC Members, on the other hand, were provided with a 50-minute fixed lecture-based learning slot, weekly, where the basic concepts and essential theories have been provided while the other two 50-minute slots were devoted to the PBL that weighted $60 \%$ of the grade. This $60 \%$ was divided so that $50 \%$ was assigned to progress, lab, and final report grades, $5 \%$ for the presentation, and 5\% for specially designed homework assignments support the project. The remaining $40 \%$ were divided so that a $10 \%$ mid-term exam was offered to make certain that the students have been grasping the new concepts and theories and a final exam of $30 \%$ to provide a collective individual assessment for each student.

\section{Courses $3 \mathcal{E}$ 4: Selected topics in construction engineering (with two different offerings -Fall $2018 \mathcal{E}$ Fall 2019)}

This course focused on two major parts: (1) project management tools and techniques applied in construction engineering, and (2) building information modeling (BIM) with an emphasis on 4D and 5D BIM applications in construction. Students were exposed to many technological tools that they needed to be equipped with once they graduated from the engineering program at Qatar University. At the beginning of the course, the instructor provided a number of fundamental preparatory lectures, which were necessary to ensure general background knowledge in project management concepts and BIM. These lectures were normally all delivered within the first four or five weeks of the fall semester. Concurrently, a laboratory component focused on the use of technology and computer-based project management tools. At the beginning of the third week, students were typically exposed to the PBL document package, which was a document outlining PBL concepts, authorizing the students to begin orienting their mindset toward PBL, and preparing them to select an appropriate project structure to be planned and BIM model to be developed.

The mandates of the course project were to develop complete 4D BIM simulations, as typically required during the planning phase of construction projects. Each group had to clearly demonstrate the knowledge gained from the preparatory lectures in defining the scope of their project, the detailed list of construction activities required to complete the project, the schedule, and the estimated budget. This part of the project had to be submitted as part of the mid-semester progress report for each group. Similarly, each group had to integrate the knowledge acquired in a number of introductory lectures on BIM as well as the standard technology tools used by the construction industry during the seventh and eighth weeks of the semester. For the remainder of the course, groups mainly utilized the PBL sessions to finish their projects' BIM models and simulations as well as for optimization of the original project schedules and activities. The final report, which was due in the last week of the semester, had to include the comprehensive components of all project requirements, such as the optimized scope, revised schedules, revised activities list, 3D BIM model and overall 4D BIM simulations, visually showing the how their selected case study could be constructed.

During the PBL session, all groups were engaged in discussion, worked on their projects, and planned their out-of-class efforts. Additionally, all groups were engaged in six special PBL sessions guided by invited industrial mentors, which assisted in accelerating the hands-on experience in the use of different BIM technology tools (such as Autodesk Rivit and Navisworks). Out-of-class efforts included reviewing approved video training resources given by the instructor, instructor's notes and handouts, textbooks, and internet sources. The role of the instructor was to coach students through engagement in these discussions. Additionally, the instructor offered four project-supporting homework assignments to help the students work tasks similar to those in their projects to maintain a shared experience and promote communication among all members of the class

In the Fall 2018 semester, the course was offered in a structured and closed-ended PBL mode with a correct solution to the given problem, while in the second offering during Fall 2019 it was an open-ended PBL, whereby the final size of the project and the requirements were kept open for all groups with diverse options of methods and solutions.

For the assessment, in Fall 2018, 55\% of the final grade was allocated for the PBL assessment as a group while the remaining $45 \%$ was allocated for individual students based on exams, quizzes and homework assignments. However, in Fall 2019 70\% of the final grade was allocated for the PBL assessment as a group, and 30\% was allocated for the individual assessment. The subcategories of the group assessment grade included the group progress report in the middle of the semester ( $25 \%$ of final grade), the group final report at the end of the semester $(40 \%)$, and four group homework assignments, which helped ensure proper alignment of each group PBL project with the general requirements (5\%). The subcategories of the individual assessment grade included a midterm examination focused on project management $(10 \%)$, a final examination focused on BIM (10\%), and individual performance during the PBL sessions and individual answers to one question embedded within the final exam, which was related to their group PBL case $(10 \%)$.

It is worth mentioning here that the most improved step in the Fall 2019 assessment is the individual assessment on BIM implementation as a technology tool 
during the final examination. All students were given a simple unified case study (for a simple civil engineering structure) adequately covering the construction management and BIM components covered in the course such as: scope definition, development of a complete list of activities, determining activities' durations, BIM modeling and generating the final simulation scenarios. Although such an assessment step was simplified during the final exam $(10 \%$ of final grade) relative to each group's submitted project, it was a very rich indicator for each student performance with respect to the overall course learning outcomes. This assessment step increased the level of confidence for both the course instructor and all students with respect to final grades.

\section{Participants}

All students in the four courses described above $(n=121)$ were invited to participate in this study. A total of $116(96 \%)$ students participated in 23 group interviews (Course 1: 30 participants from 6 teams; Course 2: 24 participants from 4 teams; Course 3: 35 participants from 7 teams; Course 4: 29 participants from 6 teams). The participants were all male, as the undergraduate civil engineering program is only available to male students.

\section{Data Generation and Analysis}

While it is suggested that engagement with learning is subjective (Wimpenny \& Savin-Baden, 2013), the majority of the literature is based on quantitative data (Trowler, \& Trowler, 2010). Multiple sources of qualitative data were generated in this study to gain a deep understanding of students' engagement in PBL and of the implementation of PBL.

Focus group interviews were conducted at the end of each course (by the coauthors who are not the instructors) as the major source of data generation method. For the purpose of understanding collective engagement, the focus groups were organized by $\mathrm{PBL}$ project teams. Following the interview techniques suggested by Kvale and Brinkmann (2009), the group interviews included semi-structured questions and probing questions that helped identify and clarify emerging topics and helped explore individual thoughts in a group setting. During the interview, participants were invited to reflect on their PBL team project process (goals, planning, progression, and outcomes) through questions such as: "Could you please describe how your project has been developing throughout the semester?", "What are the components of the project that you feel you have learned most from and why?", "How do you evaluate your project's progression according to your goals and plans?", "Can you please provide examples of how you engage with your team members on this project?", and "What are the most important factors enabling project success, in your opinion?" The interviews were conducted in English, which is the study language in the program. All interviews, lasting 30-60 minutes each, were audio-recorded and transcribed for analysis.

Observation data was used to triangulate the patterns identified from focus group analysis. Students were observed by two course instructors, who were also coauthors of the study and who played a dual role in the classroom: they acted as both PBL facilitators and as observers of students' discussions, actions, interactions, reactions, efforts and progress. Over the semester-long (four-month) project, the instructors spent intense time with the students, which provided them with insight into the students' experiences, and these insights were used for an overall judgment of students' forms and levels of engagement. The last author, a pedagogical expert in PBL, helped the instructors with their PBL course design and also worked as a non-participant observer on a weekly basis. Throughout the semester, the non-participant observer made notes on examples of student engagement and held regular discussions with the course instructors to validate the observation outcomes.

Multiple techniques were used to analyze multiple sources of qualitative data both inductively and deductively. First, following the four categories of student engagement identified by Wimpenny and SavinBaden (2013), we analyzed the group interview transcripts by clustering all the relevant answers by student groups to determine patterns. Afterwards, a thematic approach was adopted to further categorize sub-patterns by outlining the meanings of the interviewees (Kvale \& Brinkmann, 2009). In the coding process, indicators of engagement, paradoxical engagement, and disengagement were identified across the four categories (for examples, see Table 1). The two instructors/observers categorized student engagement following the same framework by project groups. Then, we compared the initial results of the interview analysis with the observation notes for triangulation. Several rounds of discussion were conducted until an agreement was reached, as presented in Table 1.

\section{FINDINGS}

\section{Student Engagement in Different Types of PBL}

The deductive analysis results suggest that engineering students indicated their engagement in all four categories identified by Wimpenny and SavinBaden (2013); nevertheless, different indicators of engagement were found in this study, highlighting the role of different PBL types. Table 1 provides an overview of the results with examples of coding and interview quotations, showing the ways students in which students were engaged within their project teams. 
Table 1. Student engagement by category with examples of citations

\begin{tabular}{|c|c|c|c|c|}
\hline & Examples of citation & & Class and group & Percentage \\
\hline \multirow[t]{7}{*}{$\begin{array}{l}\text { Engagement as } \\
\text { autonomy }\end{array}$} & $\begin{array}{l}\text { Applying theory to } \\
\text { practice and work- } \\
\text { related activities }\end{array}$ & $\begin{array}{l}\text { We learned more hand-on skills from this project linking the theories to practice, } \\
\text { for example, doing simulation with different software what will be used in the } \\
\text { profession, which is important for civil engineering... (G22) }\end{array}$ & ALL & $100 \%$ \\
\hline & $\begin{array}{l}\text { Self-sufficiency and } \\
\text { solution orientation }\end{array}$ & $\begin{array}{l}\text { Since we have to search information ourselves, we go for multiple sources and } \\
\text { find there are usually more than one way to solve things. (G12) }\end{array}$ & ALL & $100 \%$ \\
\hline & $\begin{array}{l}\text { Multiple sources of } \\
\text { learning }\end{array}$ & $\begin{array}{l}\text { We searched information from diverse sources which helped us to expand our } \\
\text { knowledge scope and ability to learn ...( G6 ) }\end{array}$ & ALL & $100 \%$ \\
\hline & $\begin{array}{l}\text { Reduced perceived } \\
\text { difficulty level }\end{array}$ & $\begin{array}{l}\text { It has been rather difficult but now much easier after we have sorted out the } \\
\text { issues in the project. (G9) }\end{array}$ & $\begin{array}{l}\mathrm{G} 2,3,4,5,6,7,8,9,10,11 \\
12,13,14,15,16,17,18,19 \\
20,21,22,23\end{array}$ & $91 \%$ \\
\hline & $\begin{array}{l}\text { Improved confidence in } \\
\text { learning engineering }\end{array}$ & $\begin{array}{l}\text { We followed the rubrics and along the project we feel more and more confident } \\
\text { that we are reaching there. (G15) }\end{array}$ & $\begin{array}{l}\mathrm{G} 2,4,5,6,7,8,9,10,11,12 \\
13,14,15,16,17,18,19,20 \\
21,22,23\end{array}$ & $96 \%$ \\
\hline & $\begin{array}{l}\text { Agency in decision } \\
\text { making and project } \\
\text { monitoring }\end{array}$ & $\begin{array}{l}\text { In the process there were many situations where we had to make choices and } \\
\text { decisions on how to solve issues, and we managed to find a way to agree on in } \\
\text { the team. (G7) }\end{array}$ & $\begin{array}{l}\mathrm{G} 3,7,8,10,12,13,14,15,16, \\
17,19,20,23\end{array}$ & $56 \%$ \\
\hline & $\begin{array}{l}\text { Reflect and making } \\
\text { corrections }\end{array}$ & $\begin{array}{l}\text { Rubrics is a good tool to help us evaluate our own work and see whether we are } \\
\text { on the track or not and what needs to be improved. (G23) }\end{array}$ & $\begin{array}{l}\mathrm{G} 3,7,8,10,12,13,14,15,17, \\
19,20,23\end{array}$ & $52 \%$ \\
\hline \multirow{3}{*}{$\begin{array}{l}\text { Engagement as } \\
\text { connection }\end{array}$} & $\begin{array}{l}\text { Connection within the } \\
\text { course }\end{array}$ & $\begin{array}{l}\text { I can see going through this project will help reach all the course leaning } \\
\text { outcomes and we also learned additionally about project management and } \\
\text { teamwork... (G5) }\end{array}$ & ALL & $100 \%$ \\
\hline & Simulation of work life & $\begin{array}{l}\text { PBL provides us with a simulation of real life for future work, like solving } \\
\text { problems, managing time, dealing with people.... (G20) }\end{array}$ & $\begin{array}{l}\mathrm{G} 2,3,5,6,8,9,10,12,13,14, \\
15,16,17,18,19,20,21,23\end{array}$ & $78 \%$ \\
\hline & $\begin{array}{l}\text { Reflection on } \\
\text { curriculum }\end{array}$ & $\begin{array}{l}\text { - It would be helpful if we lean PBL skills at an earlier stage so we can prepare } \\
\text { ourselves for the senior. } \\
\text { - The project helped me to get prepared for senior design project, so the } \\
\text { additional learning is all worth. } \\
\text { - It would be useful to coordinate with students from other programs such as } \\
\text { architecture so we can solve on the same problem with more different } \\
\text { resources. (G 23) }\end{array}$ & $\begin{array}{l}\mathrm{G} 2,5,6,8,10,12,13,14,15 \\
16,17,18,19,20,21,23\end{array}$ & $70 \%$ \\
\hline $\begin{array}{l}\text { Inter-relational } \\
\text { engagement }\end{array}$ & Treasured team & $\begin{array}{l}\text { Good chemistry, shared goals and trust are very important to make us a good } \\
\text { team. (G19) }\end{array}$ & $\begin{array}{l}\mathrm{G} 2,4,5,7,8,12,13,14,15 \\
16,17,19,20,21,23\end{array}$ & $65 \%$ \\
\hline
\end{tabular}

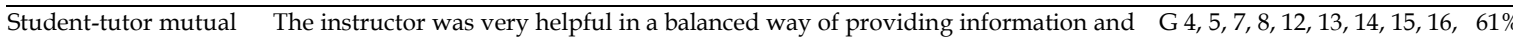
understanding letting us finding out answers...this was very important for us.... (G13)

$17,19,20,21,23$

Student-career It has been very useful to have engineers from industry to help us in the project, G11, 12, 13, 14, 15, 16, 17, 18, 56\% from them we learned timely tools and about how real work is. (G14)

$19,20,21,22,23$

Industry mentors $\quad$ For us as engineers, having the project as a major part of the course is much more G2, 11, 12, 13, 14, 15, 16, 17, 52\% useful than lectures because we have to do something with our hands, it is a $\quad 19,20,21,23$ better way to prepare for the future work. (G17)

Emotional Joy of learning We are more motivated to learn engineering in this way (PBL). It became AL

engagement engineering interesting to figure out a problem on our own and then find out how to solve it.

ALL
(G19)

Resilience and It has been difficult at the beginning, but it turned better and next time we know ALL

persistence It has been difficult at the begir

Positive attitude

towards uncertainty we would go through. (G23)

There were for sure unexpected issues such as the software was not easy to learn as we expected or even small things...but we found out solutions together and and overcoming moved on... it was a good release and feeling of achievement at the end...(G14)

\section{Dilemma of}

engagement

Following authority

- When we disagree, we usually go to the instructor to ask for the correct

$\mathrm{G} 3,4,5,7,8,9,12,13,14,15,60 \%$

$100 \%$

information. (G2)

Maybe because this kind of PBL is so new both the instructor and us, it has

been really heavy and hard, without knowing whether things are done correctly or not. (G4)

Feeling stressed due to If we have learned how to do PBL earlier when the subjects were not so difficult. G1-6, 8, 9, 10, 11, 12, 17, 18, 70\%

uncertainty about the Now all subjects in civil engineering are difficult and we have to spend more time 19, 22, 23

project

on dealing with PBL skills, each class demands lots of assignments.... We are stressed.... (G10)

Disengagement Lack of self-directed - Sometimes it can be a waste of time to search for information on our own, the and disjunction learning

instructor could just tell us directly... (G2)

$\mathrm{G} 1,2,3,4,5,6,8,9,10,11, \quad 74 \%$

Sometimes lecture time is only around 10-15 minutes, too little to grasp things

$15,16,17,18,19,21,22$

from the instructor. (G11)

- We wish to get more instructions on how to do the project according to what the instructor wants, we don't know what to do if we were not sure what he expected us to do exactly and how to get there... (G18)

\begin{tabular}{lll}
\hline $\begin{array}{l}\text { Lack of team trust and } \\
\text { dynamic }\end{array}$ & - Distribution of the work among group members is not fair.... & G1, 3, 9, 10, 11, 18, 22 \\
& - And all of us get the same grade.... (G1) & $30 \%$ \\
\hline $\begin{array}{l}\text { Lack of career } \\
\text { perspective }\end{array}$ & $\begin{array}{l}\text { For me I mainly aim to pass and finish this education, because I don't see myself } \\
\text { as a civil engineer in the future. Likely I will do something else. (Group 22) }\end{array}$ & G1, 3, 9, 10, 11, 22 \\
\hline
\end{tabular}


First, among the four categories, engagement as autonomy was the most evident type of engagement. All student groups from the four PBL courses indicated their appreciation of learning through applying theory to practice and work-related activities. They also demonstrated development of agency in choice- and decision-making. In addition, they revealed their selfsufficiency and solution orientation and relying on multiple learning sources while working in a project team. Most teams reported that the perceived difficulty of engineering projects decreased as the semester progressed. They also perceived themselves as having improved confidence in learning engineering content after completing the project.

Second, students also indicated significant engagement as connection. All students reported that their view of learning engineering changed over the course of the semester, which is an indication of engagement as connection. Engagement as connection was also reflected through students' self-reflection on how their own learning outcomes were constructively aligned with the intended learning outcomes. It was also evident in students' comments about how they became able to see connections between ideas in a way that transcended a single course and in their reflections on connections between different courses within the curriculum: more specifically, around two-thirds of the teams reported their reflection on the current overall curriculum and saw connections between courses. Taken together with students' perception that learning through PBL offers a simulation of work life, this indicates that learning via PBL in one course may give students the skills they need for courses in the next stage.

Third, students engaged emotionally as the project progressed. They experienced the joys of learning engineering through the problem-solving process and demonstrated their resilience and persistence in coping with challenges and managing the project work. Positively, more than half of the teams demonstrated affirmative attitudes toward uncertainty and overcoming unexpected issues. Lastly, while students also demonstrated strong inter-relational engagement, characterized by their connectedness to other people and concepts including team members, tutors, prospective careers and industry mentors, engagement in this category was only partially evidenced. Students in course 1 reported the lowest levels of this category of engagement, while two of the four dimensions of this category, namely, student-career and student-industry mentorship engagement, were mostly reflected by students in courses 3 and 4, which may be attributed to the seniority level of the courses.

We found that in addition to the four categories defined by Wimpenny and Savin-Baden (2013), students in this study also displayed paradoxical engagement: that is, while all groups appreciated their independent learning, they also all reported that they placed authoritative priority on their instructors as the most trustworthy source of knowledge and information. In other words, on the one hand, they appreciated the autonomy of learning and the opportunity to encounter uncertainty; on the other hand, they also relied on instructors to provide the correct answers in order to obtain a sense of security. Another example of paradoxical engagement is based on students' perception that working on projects improved their motivation and prompted them to make an effort that involved both time and energy. Yet around two-thirds of the groups also reported feelings of stress, both positive and negative. The negative stress was due to uncertainty about the project in terms of whether they were on the right track and would be able to reach the correct end. At the same time, most of the groups were able to handle the stress positively by taking it as a learning opportunity.

While all groups reported positive engagement, most of them also revealed disengagement and disjunction at certain stages of the project. During the study, we observed indicators of a lack of self-directed learning in two-thirds of the groups. Nearly one-third of the groups revealed their disengagement in relation to a lack of trust and dynamics in the team; students in these groups therefore felt it was unfair that they all received the same grade. Some students were not interested in making a strong effort due to a lack of career prospects. They were not sure whether they would be working as an engineer after graduation, so their main goal was simply to get through their education with a passing grade.

\section{Factors Influencing Student Engagement}

During the group interview sessions, the students were invited to discuss the appropriateness of different types of PBL according to the demands of the courses within the current civil engineering program. A inductive analysis identified three inter-related factors that influenced the forms and levels of students' collective engagement, namely, types of PBL implementation in relation to the nature of the course, students' and instructors' prior PBL experience, and team dynamics.

Regarding the first factor, the types and forms of PBL implementation according to the nature of the course, courses 2 and 3, which adopted better structured and more closed-ended PBL, received the most engagement indicators in all of the four categories. Students, as PBL beginners, appreciated this type of PBL because it struck a balance between independent project-based work and the provision of direct instruction. As mentioned in several group interviews, "knowing we are doing things correctly gives [a] security feeling and achievements." Course 4 also received significantly rich indicators for student engagement, although those indicators were mostly clustered in five of the six student groups. In course 1 (design-based problems, which can be either 
closed-ended PBL or open-ended PBL), the instructor chose to pilot an open-ended approach following the guidelines in the PBL literature. Although we generally observed positive results regarding engagement, students in this class, out of the four PBL courses, provided the fewest engagement indicators and the most disengagement indicators. The instructor also experienced challenges including a lack of institutional support and students' understanding of PBL.

Second, regarding students' prior experience with PBL, this factor is closely linked to the first factor, types and forms of PBL implementation according to the nature of the course. The majority of students in courses 1 and 2 had no prior experience of PBL and therefore, regardless of their engagement levels and team dynamics, expected more direct instruction and lectures from the instructor. In course 3, while most students shared the opinions of students in courses 1 and 2, nine of the 35 students had previously taken courses 1 and 2 and, since they drew from this earlier experience in order to undertake the new projects, they experienced higher levels of confidence.

Also, in regard to this factor, we note that course 4 provided a rather diverse picture: those groups with prior experience provided more indicators of engagement than those who had no prior experience. About half of the students had previously attended course 1 or course 2 , and these students were mostly in groups 1, 3, and 4 . These students expressed greater readiness for a more open-ended type of PBL during this course. As some of them mentioned, "Attending a PBL course earlier is really useful for this course. We know what to do in a project and won't get easily frustrated even [when] confronting issues. We will just solve it and move on." Their prior experiences also helped other students in their groups when it came to planning and managing the project. In particular, these more experienced students were aware that the project process would bring uncertainty and challenges, and they therefore demonstrated better confidence in overcoming emerging issues. Most students in the two groups ( 2 and 5) without prior PBL experience tended to desire for more lectures and correct answers.

We note that group 6, although it included only one student with prior PBL experience, showed a positive attitude toward open-ended PBL in this course. This may be mainly influenced by one group member who had already been working in an engineering company during the study; according to him, the PBL approach did approximate real work life. As he said, "in my company, we have to solve problems ourselves; no instructor will come to tell me what would be correct. I have to find it out myself. So it is very useful to be trained this way in our study."

In addition, students from courses 3 and 4 had been offered opportunities to receive mentorship from real engineers working in the industry. This generated added value for their project by supporting their career prospects and creating connections between study and work, which was reflected by substantial indicators.

Third, team dynamics played an important role in defining and differentiating student collective engagement among the groups. Focus group and classroom observation data agreed that the groups that reported a lower level of team dynamics $(\mathrm{G} 1,3,9,10,11$, 18 , 22) also reported the fewest indicators of engagement, in particular in the aspect of relational and emotional engagement.

\section{DISCUSSION}

\section{Student Engagement in PBL and Supporting and Constraining Factors}

Engagement with learning is a subjective experience, and when students are engaged in meaningful learning, the potential for learning new things increases (Wimpenny \& Savin-Baden, 2013). This study contributes to the field by providing students' voices on their exploration and discovery in a new pedagogical approach: PBL. The results of the study identified extensive indicators of engineering student engagement with learning in four different PBL courses, thereby offering evidence for the assumption that pedagogical approach may influence student engagement (Case, 2007, Krause \& Coates, 2008, Trowler \& Trowler, 2010). The results also specify that all categories of engagement, such as autonomy and connection, are visible for students - both PBL beginners and students with certain prior experiences - in all four courses. In a PBL context, students also engaged in learning emotionally and relationally (Savin-Baden, 2014).

Previous studies reported students' feelings of alienation as an indicator of a lack of engagement in an individual learning-focused environment (Case, 2007; Wimpenny \& Savin-Baden, 2013). This was not found in the current study, in which, instead, students reported more connection than disconnection in a PBL environment. This finding supports Kahu's (2013) emphasis on the socio-cultural context and on considering the connections of students with peers, tutors, methods of teaching and learning, materials and environments.

Nevertheless, the notion of engagement is unproblematic. Our inductive analysis identified three factors that influenced engagement forms and levels, namely, PBL forms and types in relation to the nature of the course, students' prior experiences in PBL, and team dynamics. While students developed agency in attitude, confidence, strategies and efforts, they, and in particular those who were PBL beginners, also tended to see themselves as having limited ability to become knowledge creators. They thus restricted themselves to 
being knowledge receivers and appliers and, accordingly, they saw the instructors as the authoritative providers of knowledge and expected more direct input on project work.

These aspects of our results are certainly not aligned with the intention of PBL (De Graaff and Kolmos, 2003; Helle, Tynjalä \& Olkinuora, 2006; Thomas, 2009). However, they may be highly related to the sociocultural context of student engagement within the institution (Kahu, 2013), which can be seen as a limitation to implementing PBL at the course level (Kolmos, 2017; Strobel \& van Barneveld, 2009). The factor of team dynamics can also be problematic since training for collaborative learning demands time and institutional supports (Borrego, Karlin, McNair, \& Beddoes, 2013), particularly in a socio-cultural context where students are not used to it $(\mathrm{Du}, \mathrm{Kolmos}$, Ahmed, Spliid, Lyngdorf, \& Ruan, 2020; Du, Chaaban, Sabah, AlThani, \& Wang, 2020). In sum, all three factors this study identified can both support and constrain student engagement in PBL, and they can also be related to the history and tradition of the Arabic educational culture (Du, Ebead, Sabah, Ma, \& Naji, 2019; Du, Naji, Sabah, \& Ebead, 2020; Sabah \& Du, 2018).

\section{Implications of the Study: A Proposal for an Institutionalized PBL Implementation Framework at the Course Level}

In general, the outcome of this study supports previous studies on the benefits of PBL in engineering education regarding students' positive attitude, interest, confidence, and competences in learning engineering (Kolmos, 2017). In particular, it provides further evidence supporting the understanding that PBL would be an effective teaching and learning method for civil engineering (Ahern, 2010; Beagon, Niall \& Fhloinn, 2019; Hezmi, et al., 2017; Murray, Hendry \& McQuade, 2019; Shekhar \& Borrego, 2017). In our recent studies on implementing PBL in civil engineering courses at the same institution, we noted that while engineering students increased their deep approach to learning through a PBL course, their surface approach to learning remained unchanged (Du, Ebead, Sabah, Ma, \& Naji, 2019). In other words, even though they developed positive attitudes toward teamwork, the team dynamics demanded further efforts and students tended to search for authority figures (e.g., instructors, experts) who would serve as knowledge sources (Du, Naji, Sabah, \& Ebead, 2020). This study further suggests that reasons for this dynamic may be related to the history and educational system of Arabic culture, which will take more than one PBL course to overcome. This result implicates that when instructors begins to implement PBL in their courses, they shall take into consideration of the students' cultural backgrounds, prior educational experiences in relation to student-centered learning, and readiness for accepting and adapting to PBL. It is essential to provide students with the understanding and skills related to PBL in order to maximize their learning outcomes (Du, Ebead, Sabah, Ma, \& Naji, 2019). In addition, it is equally important for the instructor to have the appropriate understanding and skills before they start implementing pedagogical innovation (Du \& Chaaban, 2020).

Another implication of this study is that regarding the experiences of the PBL instructors, the study suggests that by having their first PBL experiences, they reflected critically on the gains and lessons learned and revised their second PBL course based on their first experiences. Nevertheless, this study did not have sufficient evidence from students' perspective to document how the second PBL courses effect differently.

Further, the positive results of PBL for student engagement may inspire for more engineering instructors to consider adopting various PBL practices and modes in their current courses, thereby taking an incremental and exploratory approach to PBL implementation rather than a wholesale and permanent switch. One of the core issues of implementing PBL, in particular at the course level, is to what extent the curriculum (of a course or a program) is converted to PBL (Jonassen, 2011). Our evidence from this study does suggest that a transition is necessary to support PBL beginners in exploring and experiencing a progressive change of practices and beliefs. Such a transition may also help both instructors and students to overcome the identified challenges regarding tensions with surroundings and gain an institutional understanding of the needs and methods of support (Van Barneveld \& Strobel, 2011). In addition, the study results also imply that at an institutional level, a progressive mode of change can be adopted, and that pilot evidence should be documented and analyzed before a comprehensive, organization-wide approach to PBL implementation is decided upon.

However, this study nonetheless provides sufficient evidence to develop a framework for PBL implementation. In his theory of innovation diffusion, Rogers (1983) summarized four types of innovationdecisions: optional choices by individuals, collective choices by consensus members of an organization, authority choices by those who possess power or expertise, and contingent choices that start with a temporary choice. In the context of pedagogical innovation for PBL, the university in the given context is concerned that authority decisions, although they may be made more rapidly, may also be circumvented during their implementation (Rogers, 1983). Accordingly, the institute in the given study adopted an optional innovation-decision mode in order to encourage individual instructors to be engaged to change and create success stories so that more colleagues may eventually be convinced of the benefits of PBL. 
Table 2. An institutional framework for transforming LBL to PBL at a course level in preparation for systemic change at a curriculum level

\begin{tabular}{|c|c|c|c|c|}
\hline & Well-structured and close-end PBL & Intermediate PBL in structure and end & $\begin{array}{l}\text { Ill-structured and open-ended } \\
\text { PBL }\end{array}$ & Cross-course/discipline PBL \\
\hline $\begin{array}{l}\text { Type of courses } \\
\text { for application }\end{array}$ & $\begin{array}{l}\text { - Theory focused courses } \\
\text { (e.g. RC members, structural } \\
\text { analysis) } \\
\text { - PBL beginners }\end{array}$ & $\begin{array}{l}\text { - Non-design content courses (e.g. } \\
\text { contract) } \\
\text { - PBL beginners }\end{array}$ & $\begin{array}{l}\text { - Design-based courses } \\
\text { - Senior courses } \\
\text { - With prior experiences in PBL }\end{array}$ & $\begin{array}{l}\text { - Instructors and students are } \\
\text { with prior experiences in PBL }\end{array}$ \\
\hline \multirow[t]{2}{*}{ Problem-Based } & \multicolumn{4}{|c|}{$\begin{array}{l}\text { - Problem being formulated at the course start. } \\
\text { - Instructors establish overall theme frame and support student problem identification, analysis and formulation. } \\
\text { - Students are encouraged to use multiple sources of information for problem-solving. }\end{array}$} \\
\hline & $\begin{array}{l}\text { - Problems defined by the instructor, } \\
\text { with a certain structure of } \\
\text { procedures with preferred } \\
\text { methodology to guide the solution } \\
\text { searching process } \\
\text { - Can be in a form of a few } \\
\text { sequential tasks (e.g. creating a } \\
\text { procedure programming the } \\
\text { method) } \\
\text { - Similar problems for all teams but } \\
\text { there may certain level of differences } \\
\text { in outcomes among teams } \\
\text { - One correct solution. }\end{array}$ & $\begin{array}{l}\text { - Problems are identified in } \\
\text { collaboration between instructors' } \\
\text { proposal and students' choice } \\
\text { - More than one approach to the } \\
\text { problem-solving process but some are } \\
\text { prioritized } \\
\text { - Can be in a form of } \\
\text { progressive/interrelated subprojects } \\
\text { - More than one correct option but } \\
\text { some are prioritized. }\end{array}$ & $\begin{array}{l}\text { - Students identify authentic } \\
\text { problems from real life on their } \\
\text { own within the theme framed by } \\
\text { the instructor } \\
\text { - Multiple approaches to the } \\
\text { problem-solving process } \\
\text { - Milestones are used for status } \\
\text { reflection } \\
\text { - Multiple options for good } \\
\text { solutions. }\end{array}$ & $\begin{array}{l}\text { - Course instructors } \\
\text { collaboratively propose } \\
\text { interdisciplinary problem theme. } \\
\text { - Multiple approaches to the } \\
\text { problem-solving process } \\
\text { - Milestones are used for status } \\
\text { reflection } \\
\text { - Multiple options for good } \\
\text { solutions. }\end{array}$ \\
\hline \multirow[t]{2}{*}{$\begin{array}{l}\text { Project } \\
\text { organization }\end{array}$} & \multicolumn{4}{|c|}{$\begin{array}{l}\text { - Problem based project is the center of the course, being introduced at the course start and lasting the whole course duration with a product as } \\
\text { outcome (e.g. project report, design) } \\
\text { - Scaffolding is provided through lectures for basic theories, feedbacks, or other forms of supplementary activities in support of student projects. } \\
\text { - Process facilitation provided by the instructor and teaching assistants, facilitating learning from reflection on experiences. }\end{array}$} \\
\hline & $\begin{array}{l}\text { The overall problem may compose a } \\
\text { list of sub-problems that are related } \\
\text { to a list of theories, which breaks } \\
\text { down the project into a series of } \\
\text { subprojects with milestones and } \\
\text { status reflecting activities. }\end{array}$ & $\begin{array}{l}\text { The overall problem-solving process } \\
\text { may include a series of subprojects with } \\
\text { milestones and status reflecting } \\
\text { activities. }\end{array}$ & $\begin{array}{l}\text { The overall problem-solving } \\
\text { process may include a few } \\
\text { milestones which should be } \\
\text { supported by status reflecting } \\
\text { activities. }\end{array}$ & $\begin{array}{l}\text { The overall problem-solving } \\
\text { process may include a few } \\
\text { milestones which should be } \\
\text { supported by status reflecting } \\
\text { activities. }\end{array}$ \\
\hline Teamwork & \multicolumn{4}{|c|}{$\begin{array}{l}\text { - Students work in self-formed teams solving the problem(s) during the whole project process (5-8 students/team). } \\
\text { - Students take responsibility for team dynamics, communication, constructive feedbacks, conflict handling, peer assessment, etc. } \\
\text { - Instructors facilitate team process }\end{array}$} \\
\hline $\begin{array}{l}\text { Self-regulated } \\
\text { learning }\end{array}$ & \multicolumn{4}{|c|}{$\begin{array}{l}\text { Students shall be metacognitively, motivationally, and behaviorally active participants in their own learning process and engaged to project work } \\
\text { collaboratively through 1) goal setting, forethought, planning, and activating prior knowledge; 2) monitoring, elaboration, and organization; 3) } \\
\text { controlling, adaptation, and critical thinking; and 4) reaction and reflection. }\end{array}$} \\
\hline \multirow[t]{2}{*}{ Assessment } & \multicolumn{4}{|c|}{$\begin{array}{l}\text { Assessment shall be constructively aligned with the intended learning outcomes and PBL activities. Team-based project work takes up } \\
\text { minimum } 60 \% \text { of the overall grade (multiple methods may be included). } \\
\text { The model of } 100 \% \text { grade supporting the project is suggested for instructors and students with prior PBL experiences regarding other formats. } \\
\text { Cross-course PBL may demand rich and diverse PBL experiences. }\end{array}$} \\
\hline & $\begin{array}{l}60 \% \text { team grade (progressive } \\
\text { project report, oral presentation, } \\
\text { etc.) } \\
\text { - } 40 \% \text { individual grades in diverse } \\
\text { modes } \\
\text { - In total minimum } 60 \% \text { of the } \\
\text { grade supports the project (direct } \\
\text { and indirect relation) }\end{array}$ & 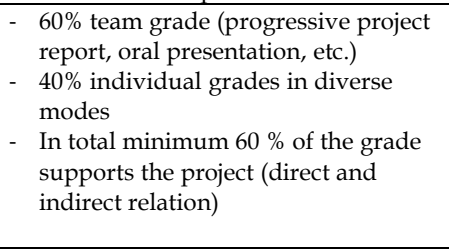 & 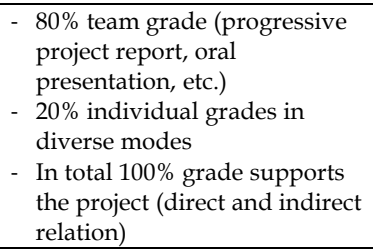 & $\begin{array}{l}\text { - } 80 \% \text { team grade (progressive } \\
\text { project report, oral } \\
\text { presentation, etc.) } \\
\text { - } 20 \% \text { individual grades in } \\
\text { diverse modes } \\
\text { - } \begin{array}{l}\text { In total } 100 \% \text { grade supports } \\
\text { the project }\end{array}\end{array}$ \\
\hline
\end{tabular}
Resources demanded for institutions:

Institutional supports in aspects of schedule, classrooms, technology (computers, software), online information/library, contact to industry, etc.

This framework, which may provide a road map for the future of PBL expansion in the institution in which this study was conducted, is shown in Table 2. This framework is based on empirical evidence and supports a progressive transformation from a lecture-based learning environment to PBL, starting with course-level changes. This progressive approach allows for a diversity of practices and a research-based approach to institutionalized pedagogical innovation. In particular, the framework is well suited for a context in which the educational history, system, policy and culture favor lecture-based learning and in which teachers are viewed as the authority of knowledge (Du, Ebead, Sabah, Ma, \& Naji, 2019; Du, Naji, Sabah, \& Ebead, 2020). In addition, the framework also proposes the developmental progressions for PBL implementation to move from a novice to experienced course level, and to further develop cross-courses and disciplinary forms.

Table 2 mainly provides description of a two-way matrix. Along the horizonal and vertical dimensions of the matrix there are several indicators that are best summarized in Figure 1a and Figure 1b, respectively. The full description of each element of this matrix for the specific horizontal and vertical dimension is listed in Table 2.

As shown in both Figure 1 and Table 2, the implementation of PBL within a course can fall into four types: well-structured and close-end PBL, intermediate PBL in structure and end, ill-structured and open-ended PBL, and cross-course/discipline PBL. In addition, six core factors are emphasized for the instructor to consider teaching design for PBL, including types of courses (nature of the subject), how to define the problem to be 


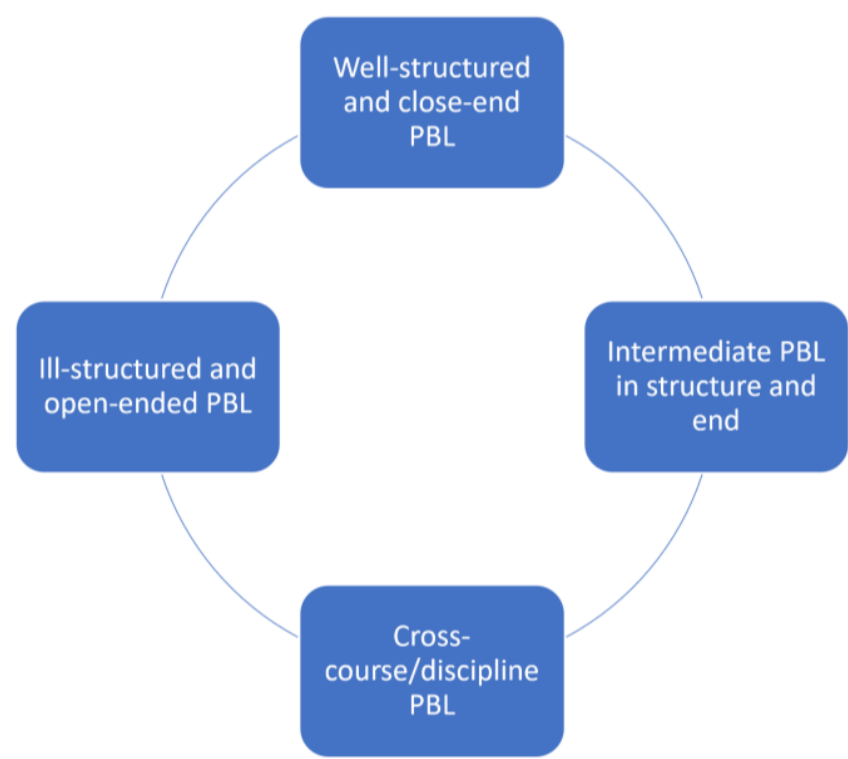

(a)
Type of

courses for

application

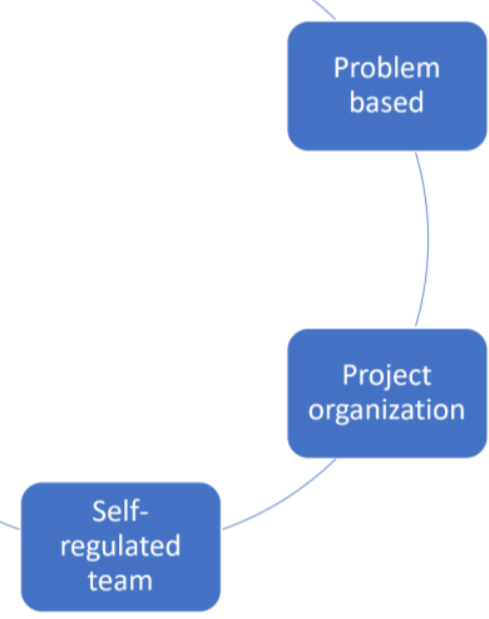

(b)

Figure 1. Horizontal and vertical dimensions of the matrix provided in Table 2

solved, how to organize the project work, self-regulation in the learning process, how teamwork may function, and how to assess the learning outcomes in order to be constructively aligned with the learning goals and the PBL method (Biggs \& Tang, 2011)

Addressing the students' voices evidenced in this study and following the PBL types summarized by Jonassen (2011) and Saven-Baden (2014), three PBL types and forms are suggested in this framework. The framework establishes (and Table 2 provides details of) the baselines and the common features of PBL course components including the problem (well-structured and closed-ended vs. ill-structured and open-ended), project (by length and scope), teamwork (formation, roles, leadership, responsibilities), student-regulated learning (student responsibility for goal setting, planning, monitoring, reflection and revision, evaluation of the project), and assessment/grade percentage (group vs. individual grade, project-related vs. non-related grades). Within this framework, instructors and students shall have the autonomy and space to develop different PBL approaches that fit the nature of the course (application or theory-focused) and student characteristics (with or without prior experience). Based on their initial experiences of PBL, instructors and students can further develop cross-course/disciplinary PBL before the scope of PBL within the institution is further expanded to an integrated curriculum (Kolmos, 2017). In addition, the framework also addresses the demand for the institution to provide the necessary support for implementing PBL (Van Barneveld \& Strobel, 2019).

While fidelity is crucial to the outcome of innovation, adaptation is an inevitable and sometimes necessary process to adjust innovation to meet local needs and conditions (Du, Chaaban, \& AlMabrd, 2019; HmeloSilver, 2012). In the process of negotiating a balance between the ideal ways of implementing PBL and the local context, both instructors and students become activators of innovation modification. However, stronger effects of implementing pedagogical innovation may take five or more years to become observable (Borman, Hewes, Overman, \& Brown, 2003). Following this, the ongoing change initiatives toward PBL in the current study should include a long-term plan with a cyclic process of implementing PBL, as proposed in our framework, requiring constant evaluation, reflection and revision before cultural change can be observed (Du \& Chaaban, 2020; Graham, 2018) and before a more satisfactory model of institutionalized PBL with integrated curricula fitting the local context can be realized (Graham, 2018; Kolmos, 2017).

\section{CONCLUSION}

The study contributes to the literature on PBL implementation in engineering education by providing empirical evidence of student engagement at the course level. Supported by empirical data from observation and group interviews with 23 project teams (116 students) from four different PBL courses in Qatar, the study identified team-based patterns regarding four different types of engagement. While participants demonstrated significant indicators of engagement as autonomy and as connection, they reported positive yet slightly fewer indicators of relational and emotional engagement. The study also identified three influential factors, namely, PBL types in relation to the nature of the course, students' prior experiences with PBL, and team dynamics. Based on these results, we establish an institutional framework supporting a progressive approach to PBL adoption, starting from diverse practices at the course level. This framework aims to provide an institutionalized approach to the transition to 
PBL in a socio-cultural context where the integration of courses is unrealistic and instructors are seen as the primary authority and source of knowledge. The study shows that implementing PBL at the systemic level is an ideal and may be an ultimate goal, but many institutions must go through a transition process to overcome institutional challenges. This framework supports an institutionalized vision and plan to manage the change from a lecture-based mode to PBL in a non-western context.

While this study provides insights into student engagement as observed in four different approaches to PBL implementation at the course level, each lasting a single semester, the results remain provisional due to a few limitations. First, the research design only compared PBL courses and was unable to also compare non-PBL courses or other forms of PBL implementation, such as those at the cross-course or program level, for example. Future studies may expand the scope of comparison to include more forms of PBL implementation and student engagement modes in non-PBL settings to draw stronger conclusions about the role of PBL in student engagement.

Second, although we included individual opinions obtained through group interviews, some sensitive aspects of those individual opinions, such as students' experiences of tension within a project team, may not have been included in the overall picture obtained through these group interviews. Further, the student participants in this study were all male, and future studies are necessary in order to more thoroughly investigate the role of gender, ethnicity, educational background, and intercultural collaborative learning environments (e.g., international mobility programs), which are all contextual factors that may impact the characteristics of collective student engagement. In addition, the institutionalized framework proposed here, although established on the grounds of empirical studies, still uses a small sample size of four courses. It thus demands further validation through follow-up studies on diverse practices of PBL implementation.

\section{REFERENCES}

ABET (Accreditation Board for Engineering and Technology). (2016). Criteria for Accrediting Engineering Programs, 2016 - 2017. Retrieved from http:/ / www.abet.org/accreditation/accreditation -criteria/criteria-for-accrediting-engineeringprograms-2016-2017/

Ahern, A. A. (2010). A case study: Problem-based learning for civil engineering students in transportation courses. European Journal of Engineering Education, 35(1), 109-116. https:/ / doi.org/10.1080/03043790903497328

Beagon, Ú., Niall, D., \& Ní Fhloinn, E. (2018). Problembased learning: student perceptions of its value in developing professional skills for engineering practice. European Journal of Engineering Education, 44(6), 850-865. https://doi.org/10.1080/03043797. 2018.1536114

Biggs, J. B., \& Tang, C. (2011). Teaching for quality learning at university: What the student does. UK: McGrawHill education.

Borman, G. D., Hewes, G. M., Overman, L. T., \& Brown, S. (2003). Comprehensive school reform and achievement: A meta-analysis. Review of educational research, 73(2), 125-230. https://doi.org/10.3102/ 00346543073002125

Borrego, M., Karlin, J., McNair, L. D., \& Beddoes, K. (2013). Team effectiveness theory from industrial and organizational psychology applied to engineering student project teams: A research review. Journal of Engineering Education, 102(4), 472512. https:/ / doi.org/10.1002/jee.20023

Case, J. (2007). Alienation and engagement: Exploring students' experiences of studying engineering. Teaching in Higher Education, 12(1), 119-133. https://doi.org/10.1080/13562510601102354

Chen, J. B., Kolmos, A., \& Du, X. Y. (2020). PBL in Engineering Education - Forms of Implementation and Challenges: A Review of Literature. European Journal of Engineering Education. https://doi.org/ 10.1080/03043797.2020.1718615

De Graaff, E., Kolmos, A., 2003. Characteristics of problem-based learning. International Journal of Engineering Education, 19(5), 657-662.

Du, X. Y., Chaaban, Y., Sabah, S., Al-Thani, A. M., \& Wang, L. (2020). Active Learning Engagement in Teacher Preparation Programs - a Comparative Study from Qatar, Lebanon and China. Asia Pacific Journal of Education, 1-16. https:/ / doi.org/10.1080/ 02188791.2020.1717436

Du, X. Y., Kolmos, A., Ahmed, M. A. H., Spliid, C., Lyngdorf, N., \& Ruan, Y.J., (2020). Impact of a PBLBased Professional Learning Program in Denmark on the Development of the Beliefs and Practices of Chinese STEM University Teachers. International Journal of Engineering Education, 36(3), 940-954.

Du, X. Y., Naji, K. K, Sabah, S., \& Ebead, U. (2020). Engineering students' group-based strategy use, forms of collaboration and perceptions of assessment in team projects - a case study in Qatar. International Journal of Engineering Education, 36(1(B)), 296-308.

Du, X., \& Chaaban, Y. (2020). Teachers' Readiness to change to Project based learning in Qatari government schools. Interdisciplinary Journal of Problem Based Learning. In Press.

Du, X., Chaaban, Y., \& AlMabrd, Y. M. (2019). Exploring the Concepts of Fidelity and Adaptation in the Implementation of Project Based Learning in the 
Elementary Classroom: Case Studies from Qatar. International Journal of Learning, Teaching and Educational Research, 18(9), 1-22. https://doi.org/ 10.26803/ijlter.18.9.1

Du, X., Ebead, U., Sabah, S., Ma, J., \& Naji, K. K. (2019). Engineering Students' Approaches to Learning and Views on Collaboration: How do both Evolve in a PBL Environment and What are their Contributing and Constraining Factors?. EURASIA Journal of Mathematics, Science and Technology Education, 15(11), em1774. https:/ / doi.org/10.29333/ejmste/ 106197

Felder, R. M., \& Brent, R. (2003). Designing and teaching courses to satisfy the ABET engineering criteria. Journal of Engineering Education, 92(1), 7-25. https:/ / doi.org/10.1002/j.2168-9830.2003.tb00734.x

Graham, R. (2018). The global state of the art in engineering education. Massachusetts Institute of Technology (MIT) Report, Massachusetts, USA. Retrieved on 15 November 2019 from https:/ / www.cti-commission.fr/wpcontent/uploads/2017/10/Phase-1-engineeringeducation-benchmarking-study-2017.pdf

Helle, L., Tynjalä, P., \& Olkinuora, E. (2006). Projectbased learning in post-secondary educationtheory, practice and rubber sling shots. Higher Education, 51(2), 287-314. https:/ / doi.org/10.1007/ s10734-004-6386-5

Hezmi, M. A., Saari, R., Mustaffar, M., Ismail, C., Hanapi, M. N., Yunus, M., ... Sulong, N. (2017, November). Enhancing Civil Engineering Professional Skills through Survey Camp Course using Project-Based Learning. In 2017 7th World Engineering Education Forum (WEEF) (pp. 285-289). IEEE.

Hmelo-Silver, C. E. (2012). International perspectives on problem-based learning: Contexts, cultures, challenges, and adaptations. Interdisciplinary Journal of Problem-Based Learning, 6(1), 3. https:/ / doi.org/10.7771/1541- 5015.1310

Jonassen, D. (2011). Supporting problem solving in PBL. Interdisciplinary Journal of Problem-based Learning, 5(2), 8. https:/ / doi.org/10.7771/1541-5015.1256

Kahu, E. (2013). Framing student engagement in higher education. Studies in Higher Education, 38, 758-773. https: / / doi.org/10.1080/03075079.2011.598505

Kolmos, A. (2017). PBL Curriculum Strategies: From Course Based PBL to a Systemic PBL Approach. In A. Guerra, R. Ulseth, \& A. Kolmos (Eds.). PBL in Engineering Education: International Perspectives on Curriculum Change (pp. 1-12). Rotterdam: Brill Sense.

Krause, K. L., \& Coates, H. (2008). Students' engagement in first-year university._Assessment $\mathcal{E}$ Evaluation in
Higher Education, 33(5), 493-505. https://doi.org/ $10.1080 / 02602930701698892$

Kvale, S., \& Brinkmann, S. (2009). Interviews: Learning the craft of qualitative interviewing. London: Sage.

Murray, M., Hendry, G., \& McQuade, R. (2019). Civil Engineering 4 Real (CE 4 R): co-curricular learning for undergraduates. European Journal of Engineering Education, 1-23. https:/ / doi.org/10.1080/03043797. 2019.1585762

Roger, E. (1983). Diffusion of innovations. 3 (ed). New York: The Free Press.

Sabah, S., \& Du, X. (2018). University faculty's perceptions and practices of student centered learning in Qatar: Alignment or gap?. Journal of Applied Research in Higher Education, 10(4), 514533. https:/ / doi.org/10.1108/JARHE-11-2017-0144

Savery, J. R. (2015). Overview of problem-based learning: Definitions and distinctions. In A. Walker, H. Leary, C. Hmelo-Silver, and P. A. Ertmer (eds), Essential readings in problem-based learning: Exploring and extending the legacy of Howard S. Barrows, pp 515. West Lafayette, Indiana: Perdue University Press.

Savin-Baden, M. (2014). Using Problem-based Learning: New Constellations for the 21st Century. The Journal on Excellence in College Teaching, 25(3\&4), 197-219.

Shekhar, P., \& Borrego, M. (2017). Implementing projectbased learning in a civil engineering course: A practitioner's perspective. The International journal of engineering education, 33(4), 1138-1148.

Strobel, J., \& van Barneveld, A. (2009). When is PBL more effective? A meta-synthesis of meta-analyses comparing PBL to conventional classrooms. The Interdisciplinary Journal of Problem-based Learning, 3(1), 44-58. https://doi.org/10.7771/1541-5015. 1046

Thomas, I. (2009). Critical thinking, transformative learning, sustainable education, and problembased learning in universities. Journal of Transformative Education, 7(3), 245-264. https:/ / doi.org/10.1177/1541344610385753

Trowler, V. \& Trowler, P. (2010). Student engagement literature review. York, UK: Higher Education Academy.

Van Barneveld, A., \& Strobel, J. (2011). Reports from teaching practice: experiences and management of tensions encountered with PBL implementations in the early years of undergraduate engineering education. Proceedings of the Research in Engineering Education Symposium 2011. Madrid.

Van Barneveld, A., \& Strobel, J. (2019). Extent and Depth of PBL Implementation - Survey results from over 300 PBL-implementing US engineering educators. 
Proceedings of the Eighth Research in Engineering Education Symposium Cape Town. July 10-12, 2019.

Wimpenny, K., \& Savin-Baden, M. (2013). Alienation, agency and authenticity: a synthesis of the literature on student engagement. Teaching in Higher Education, 18(3), 311-326. https://doi.org/ $10.1080 / 13562517.2012 .725223$

\section{http://www.ejmste.com}

